\title{
Studies of the Scope of Accepting Cases of CICC
}

\author{
Sijia Hao \\ School of Humanities and Law \\ North China University of Technology \\ Beijing, China
}

\begin{abstract}
With the gradually strengthening of globalization of the world, a number of nations have also had more and more transnational commercial disputes. Domestic arbitration and litigation in the traditional sense can no longer meet the needs of the good settlement of such disputes, as a result, there comes up the "International Commercial Court". Britain, Dubai, Singapore and other countries have taken the lead in setting up the court that dedicates to resolving the international commercial disputes, and in China, the International Commercial Court (CICC) has been established against the background of "One Belt and One Road". As is known to all, the most important thing for the operation of a court is its jurisdiction. This paper is based on the relevant regulations issued by the Supreme People's Court, and deeply analyzes the problems which exist in the jurisdiction of CICC and proposes corresponding solution.
\end{abstract}

Keywords-CICC; scope of accepting cases; internationality; commercial nature; effectively connected principle

\section{INTRODUCTION}

Since the beginning of the new century, especially since the outbreak of the international financial crisis, international economic relations and their dispute settlement have become increasingly complex and severe. UNCITRAL figures out: for the existing settlement methods of disputes, it is difficult to effectively deal with a series of problems that are arising from this new situation, and one way to improve this is to establish the specialized international commercial court, which is based on 30 years of international investment arbitration data ${ }^{1}$.

As a consequence, there has established a number of international commercial courts.

In 2006, Dubai International Financial Center Court (DIFC Court) had started, and Qatar International Court and Dispute Resolving Center (QICDRC) had been established in 2009. And in 2015, Singapore International commercial Court (SICC) had also been set up. Then Kazakhstan, India and ABU Dhabi have launched laws and established AIFCC, Indian Commercial Court and ADGMC respectively. The Netherlands Commercial Court (NCC) was launched in July, 2017, and in October, the Belgian government has passed a bill establishing the Brussels international commercial court (BIBC). In February, 2018, the French court of appeal in

Liao Yuyi. The Latest Development an Enlightenment of the Foreign Construction of International Commercial Courts.
Paris announced to establish a new French-English bilingual international commercial court, in the same year, Germany issued "Introduce International Commercial Court Legislation Draft" and was ready to establish "International Commercial Court" all over the Germany, in April. ${ }^{2}$

In China, with the proposal and deepening of the "One Belt and One Road" idea, the number of transnational commercial disputes which are along the "One Belt and One Road" have been increasing, and the Supreme People's Court has been providing judicial services and guarantees for the construction of "One Belt and One Road". One of these efforts is the establishment of China international commercial court in Xi'an and Shenzhen, so that the first international commercial court and the second international commercial court are built respectively. The relevant regulations issued by the Supreme People's Court clearly define the nature, name and locations of the international commercial court, job requirements of judges and other issues. Among these issues, the stipulations on the scope of accepting cases are still inadequate, which is the core of this paper. International jurisdiction is an important condition for a court to try civil and commercial cases, because this is the first problem to resolve. ${ }^{3}$ Although article 2 and article 3 of the regulation issued by the Supreme People's Court make the cases clearly that can be accepted by CICC through enumeration, there are still many problems. This paper will analyze the existing jurisdictional provisions, find out the existing deficiencies, and then draw suggestions for improvement.

\section{The MAIN PROBlemS AND THE SUGGESTIONS FOR IMPROVEMENT}

\section{A. "Internationality" Standards}

In the past decade, international commercial courts have appeared in four jurisdictions: DIFC Court, QICDRC, AIFCC and SICC. These four courts have been described as "particularly accepted to the needs and realities of international business". ${ }^{4}$ One of these four courts - SICC takes a mixed approach, which is taking into account both

\footnotetext{
2 Shan Wenhua. The Foreign Experience of Building International Commercial Court and Chinese Contribution, China Trial, 2018.

3 Li Wang. Private International Law, Law Press, China, 2011: p270.

Godwin: Andrew. International Commercial Courts: The Singapore Experience, Melbourne Journal of International Law, 2017.
} 
the standards of substantive connection and the standards of the nature of disputes, to recognize the "internationality" of a case. On the basis of article 1 (2), subparagraph (a) of the Order 110 of the Rules of SICC: "In this Order, unless the context otherwise requires--a claim is international in nature if - (i) the parties to the claim have their places of business in different States; (ii) none of the parties to the claim have their places of business in Singapore; (iii) at least one of the parties to the claim has its place of business in a different State from - (A) the State in which a substantial part of the obligations of the commercial relationship between the parties is to be performed; or (B) the State with which the subject matter of the dispute is most closely connected; or (iv) the parties to the claim have expressly agreed that the subject-matter of the claim relates to more than one State." Otherwise, our country's provisions on the "internationality" of the cases under the jurisdiction of CICC are as follows: (i) one or both of the parties is a foreigner, stateless person, foreign enterprise or organization; (ii) the habitual residence of one or both parties is outside the territory of the People's Republic of China; (iii) the subject matter is outside the territory of the People's Republic of China; (iv) the legal facts of the emergence, alteration or termination of commercial relations occur outside the territory of the People's Republic of China. This is according to article 522 of Interpretations of the Supreme People's Court on the Application of the Civil Procedure Law of the People's Republic of China to elaborate, but it does not have Miscellaneous Provision.

By contrast, firstly, it can be known that the stipulations in our country state the subject of natural person, while from the rules of SICC; it is clear that it mainly lists the legal person and takes "place of business" as the identification standard. In addition, it can be seen from the related legislation in Singapore that Singapore sees itself as a neutral third country and not as the judgment criteria when it accepts the international business cases. However, the "foreignrelated factors" stipulated by our country are still located in China to look for overseas factors, not as the neutral situation to define the "internationality", and this will lead to a domestic case in which all the elements of a legal relationship are located in a foreign country also meets the foreign requirements. If it is seen from the standpoint of universalism, it is more consistent with the practice of international commercial transactions to find the overseas factors that affect the dispute substance based on the business place of the subject of the dispute rather than the place of the court.

In addition, the provision of CICC does not have the Miscellaneous Provision; it means that this will limit the discretion of a judge and the jurisdiction of the court. From the author's point, there are only three international commercial courts in China - in Peking, Xi'an and Shenzhen, and at the beginning, the number of the judges is not enough, so shrinking jurisdiction can reduce the number of the cases. This is able to reduce the workload of judges and improve the quality of trials. However, narrowing the scope of accepting cases will also keep many foreign-related cases out, and this can lead to the parties cannot choose
Chinese courts for the trial of the disputes. The author thinks, such provisions have certain advantage in the early stage, but as the maturity of the court, it is also needed to increase the number of accepting cases by adding the Miscellaneous Provision.

In the end, is this a good rule? From the provisions of the "internationality" in China, the theory of "three elements concerning foreign affairs" has always occupied the mainstream position in the legal field of China. ${ }^{5}$ Foreign civil legal relationship means that everything in the subject, object, rights and obligations includes one or more factors having contact with the foreign country. If the subject is a foreign factor, which means that one or both parties as the subject are foreign natural persons, foreign legal persons or foreign organizations; if the object is a foreign factor, which refers to the fact that the object or property of civil relationship is located in a foreign country or the civil act needs to be implemented or completed in a foreign country; if the rights and the obligations are the foreign factors, which means that the legal facts which lead to rights and obligations to arise, change or be eliminated occur in a foreign country. This definition is the theoretical basis of the traditional foreignrelated civil legal relations, and the viewpoints represented by this theory are accepted completely by judicial practice in China. However, traditional "three elements theory" has its drawbacks. Firstly, subjects lack flexibility. The Chinese laws always use the Registered Localism to determine the habitual residence of a legal person. ${ }^{6}$ In this situation, foreign-invested enterprises whose registration places are in China are also deemed to have no foreign-related factors and a legal person who is established in accordance with Chinese law and within the territory of China by a wholly foreignowned enterprise is a Chinese legal person. If they have disputes, the court will generally characterize the case as purely domestic case. However, foreign-invested enterprises, whose capital comes from foreigners, interests are ultimately belong to foreigners and their business decisions are generally closely related to their foreign investors, will lose the possibility of the application of laws which will make it comfortable for them. In order to increase the possibility of applying laws that make investors comfortable, the question of the source of corporate capital or the nationality of the capital controller can be considered. Secondly, it expands the scope of performance behaviors. According to the current judicial practice in China, the scope of the performance behavior is very narrow, ${ }^{7}$ and this means that only make the performance behaviors which implement the final legal status to be the object of study. However, in "Siemens case" and "Shanghai golden land case", the courts have, in a breakthrough, supplemented the scope of the performance

\footnotetext{
5 Wang Xiaojiao. Second Thoughts on the Definition of "Foreignness" in Foreign-Related Civil Relations — also the "Interpretations of the Supreme People's Court on the Order of the President of the People's Republic of China(I)", Journal of Xinjiang University, 2013

6 Zhang Xiaodong, Dong Jinxin. Try to Discuss the Definition of the Standard of Foreign Private International Law, Presentday Law Science, 2010 .

Qi Huan. The Definition and Thinking of Foreign Civil Relationship, Tsinghua University Law Journal, 2017.
} 
behaviors, which means that import, customs clearance and a series of performance behaviors are included in the scope of investigation. As a result, the author thinks, when investigating the foreign-related factors in the performance of both parties, the consideration for determining a foreignrelated factor should not only be the act that shapes the legal status, but also the whole performance behaviors, including import, customs clearance and other behaviors.

\section{B. "Commercial Nature" Standards}

In China, Civil Procedure Law and Arbitration Law both do not include the term of "commerce", and instead, they use "contract or other property rights disputes". In practice, "contract or other property rights disputes" mainly refers to disputes arising from contractual or non-contractual obligations, but from the point of concept, the scope of property rights disputes is broader than commercial disputes, which does not accord with the trend of specialization of international commercial court obviously. ${ }^{8}$ "One Belt and One Road" construction is mainly economic cooperation, so disputes arise in trade area and investment area inevitably. There are three main types of disputes. The first one is trade disputes between countries. To resolve this kind of dispute, in addition to negotiation, China currently accepts the WTO dispute settlement mechanism. The second one is an investment dispute between an investor and the host country. At present, the solutions accepted by China is embodied in the bilateral investment protection agreement signed by our country, including ICSID mediation and arbitration mechanism, applying UNCITRAL arbitration rules and other ways. The third one is disputes between equal commercial subjects in trade, investment and other fields. To resolve this dispute, arbitration, mediation and trial are all universal relevance. CICC is built for the third type of disputes. However, the provisions do not have the definition of "commercial nature". Rules of SICC adopt an incomplete enumeration and the last article also fully demonstrates respect for the parties' will of autonomy. ${ }^{9}$

The Supreme People's Court has defined the commercial legal relationships specifically. Article 1, paragraph 3, of United Nations Convention on the Recognition and Enforcement of Foreign Arbitral Awards allows states parties to make commercial reservations when acceding to the convention, so our country make the commercial reservation, which is Notice of the Supreme People's Court

8 Gu Hao, Lin Yufang. Preliminary Study on CIII, Journal of Dalian Maritime University, 2018.

9 Article 1 (2), subparagraph (b) of the Order 110 of the Rules of SICC: a claim is commercial in nature if - (i) the subject matter of the claim arises from a relationship of a commercial nature, whether contractual or not, including (but not limited to) any of the following transactions: (A) any trade transaction for the supply or exchange of goods or services; (B) a distribution agreement; (C) commercial representation or agency; (D) factoring or leasing; (E) construction works; (F) consulting, engineering or licensing; (G) investment, financing, banking or insurance; (H) an exploitation agreement or a concession; (I) a joint venture or any other form of industrial or business cooperation; (J) a merger of companies or an acquisition of one or more companies; $(\mathrm{K})$ the carriage of goods or passengers by air, sea, rail or road; (ii) the claim relates to an in personal intellectual property dispute; or (iii) the parties to the claim have expressly agreed that the subject matter of the claim is commercial in nature; on Implementing the Convention on the Recognition and Enforcement of Foreign Arbitral Awards Acceded to by China. This notice stipulates "contractual and noncontractual commercial legal relations", which refers to economic relationship of rights and obligations arising out of contracts, tort or in accordance with relevant legal provisions.

The author thinks that the judgment of "commercial nature" of disputes is also the top priority. If determine the scope of cases of CICC according to the Notice, the intellectual property disputes and maritime disputes will overlap with the jurisdiction of China's existing intellectual property courts and maritime courts. As a result, the certainty of "commercial nature" in imminent, we should learn from other countries' provisions and rely on Chinese situations.

\section{Effectively Connected Principle}

Jurisdiction by agreements is the main basis for establishing jurisdiction of international commercial courts. The scope of jurisdiction of CICC relies on the choosingcourts of parties and the chosen court must be limited by "effectively connected principle" of 34th article of Civil Procedure Law. China has been insisting in "effectively connected principle", it can be seen from it that this principle has its positive meanings, but the negative effect is that it hinders the parties from choosing a neutral third country court.

Offshore case is the case which is no practical connection between admissibility and the court, which is the main factor of international commercial court. The international commercial courts established by states also intend to attract cases that have no real connection to the places of courts. In Singapore, from the provision about "jurisdiction by agreements, it can be known that SICC try its best to give the parties the maximum autonomy. Rules of SICC stipulate: the Court must not decline to assume jurisdiction in an action solely on the ground that the dispute between the parties is connected to a jurisdiction other than Singapore, if there is a written jurisdiction agreement between the parties. By contrast, in China, there are only two international courts, which are in Xi'an and Shenzhen respectively, if "Effectively Connected Principle" is used, does that mean the cases only have real connection with these two places? In this situation, the cases which can be accepted by the international commercial courts are too few. As a result, it should be considered whether CICC should continue to adhere to the "Effectively Connected Principle".

The late Mr. Li Haopei, a famous international private jurist in China, once criticized the "Effectively Connected Principle" which is required in jurisdiction agreement in China. Mr. Li thought that:" This kind of requirement can rule out the possibility of parties agreeing to grant direct international jurisdiction to a neutral court, and this is adverse to the development of international economic intercourse. Legal subjects who sign agreement to make international trade, no matter natural persons or legal persons, are usually belonging to two different countries. These legal subjects usually tend to maintain the prestige of their respective national judicial systems, and there is always a 
lack of trust in the other side's nation's judicial system. So the tendency of modern international civil procedure laws does not require the parties choose the courts whose places have the effectively connected with the disputes." ${ }^{10}$ In China, Special Maritime Procedure Law of the People's Republic of China breaks the "Effectively Connected Principle". The 8th of this law stipulate that if the parties have agreement to choose Chinese court, the maritime court of the People's Republic of China also has jurisdiction over the dispute, though some cases do not have real connection with territory of China. With the implementation of the spirit of private law autonomy and the expansion of the democratic principle of litigation, the dominant position of litigants in also will strengthen further. On the basis of full consideration of all relevant interests and factors in the cases, the comprehensive game and negotiation between the two parties when choosing the court of jurisdiction can weigh the pros and cons of the individual parties, which is far more than the courts and judges who represent the public power.

\section{CONCLUSION}

The construction of CICC is the supporting measure of "One Belt and One Road" construction in China, and the aim is to serve for the development of "One Belt and One Road" better. Jurisdiction is the basis for the operation of the court, the basic condition for accepting cases, and also an important means to fight for the source of international commercial disputes. The establishment of CICC is an innovation of traditional jurisdiction, and at the same time, some breakthroughs have been made in the jurisdiction of CICC. However, according to the analysis above, the jurisdiction of CICC still have room for improvement. China can take example by the relevant provisions of other experienced countries and combine its practical situations to continue to launch relevant supporting measures for improvement.

\section{REFERENCES}

[1] Liao Yuyi. The Latest Development an Enlightenment of the Foreign Construction of International Commercial Courts.

[2] Shan Wenhua. The Foreign Experience of Building International Commercial Court and Chinese Contribution, China Trial, 2018.

[3] Li Wang. Private International Law, Law Press, China, 2011: p270.

[4] Godwin: Andrew. International Commercial Courts: The Singapore Experience, Melbourne Journal of International Law, 2017.

[5] Wang Xiaojiao. Second Thoughts on the Definition of "Foreignness" in Foreign-Related Civil Relations - also the "Interpretations of the Supreme People's Court on the Order of the President of the People's Republic of China(I)", Journal of Xinjiang University, 2013.

[6] Zhang Xiaodong, Dong Jinxin. Try to Discuss the Definition of the Standard of Foreign Private International Law, Presentday Law Science, 2010.

[7] Qi Huan. The Definition and Thinking of Foreign Civil Relationship, Tsinghua University Law Journal, 2017.

[8] Gu Hao, Lin Yufang. Preliminary Study on CIII, Journal of Dalian Maritime University, 2018.

[9] Li Haopei. An Introduction of International Civil Procedure Law, Law Press, China, 1996.

10 Li Haopei. An Introduction of International Civil Procedure Law, Law Press, China, 1996. 